\title{
EFFECT OF TOURISTS HARASSMENTS TO THE DESTINATION IMAGE AND REPEAT VISIT INTENTION OF TOURISTS: A CASE STUDY OF SRI LNAKA
}

\author{
R.S.S.W. Arachchi \\ Department of Tourism Management, Faculty of Management Studies, \\ Sabragamuwa University of Sri Lanka
}

\begin{abstract}
Beach sites are considered as one of the major travel motives of the tourists to visit Sri Lanka. Sri Lanka is rich with wonderful beach sites including Hikkaduwa, Unawatuna, Bentota. However, many tourists visiting Sri Lanka have to undergo many forms of harassment. Ensuring safety of tourists in the tourists' destinations is an important factor to retaining the higher number of tourist arrivals to the country since it is significance to the Sri Lankan Economy. Amidst to this background, the main objective of this study is to identify the types of the harassments faced by the tourists at beach sites in Sri Lanka and to identify the impact of tourists' harassments to the destination image and the propensity to repeat. Both qualitative method and quantitative method used to carry out the study. Primary data for the research were collected using a questionnaire survey with tourists and the discussions with the community members, site guides, hoteliers, officers who work in tourism related organizations. Further, secondary data were collected using articles published in the internet, tourists police reports (RTC-PTD Report) and tourist magazines. Both systematic random sampling method and convenience sampling method used for the study, respectively sample the foreign tourists from Hikkaduwa and the inter-viewers. The study revealed that the tourists who stay at Hikkaduwa undergo of harassments from different parties like beach boys, pesters, thieves...etc. These harassments create dissatisfaction among the tourists and it also affect for the destination image and the propensity to repeat.
\end{abstract}

Keywords: Tourist Harassment, Beach sites, Hikkaduwa, Sri Lanka, Tourist Satisfaction

\section{Introduction}

In present era, tourism is the most attractive and the fastest growing industry in the world. It has become an economically important sector to both developed and developing countries including Sri Lanka. Sri Lanka is one of the most sorts for tourist destinations in the world. It is bounded by the Indian Ocean strategically located between West Asia and South East Asia. It has been an important stop on the silk route or the Silk Road. It has all necessities to become one of the best tourist destinations in the world. It contains mixture of breathing landscape, misty hills, rare unique wild life, rich cultural tradition and heritage, tropical weather as well as delightful beaches. Sri Lanka is a small universe, it contains as many variations of culture, scenery and climate as some countries a dozen times its size. It is a destination which consists with both natural and man-made attractions. Those are added value to the country. These kinds of natural and man-made attractions create a high demand for the country as a destination. As a result of that tourists prefer to get the memorable experience during their tour with these natural and man -made attractions. Because of that tourist arrivals are increasing dramatically. As a service industry tourism industry is a booming industry. When we are considering about the forms of tourism in Sri Lanka, beach tourism is one of the famous forms of tourism. There are so many attractions and recreational activities in the beach areas such as swimming, sun bathing, snorkeling and various water sports 
activities. When the number of tourists is increasing in the destination, sometimes local see them as an opportunity earn money. As a result, they approach to them and earn some income providing some services. There, host and guests' conflicts can be occurred. If the tourists are not supportive to locals, then they have a negative attitude towards them. As a result, harassments can be happened.

\section{Research gap}

The researcher studied tourism related research articles published in the reputed journals. The researcher found few research articles related to harassments of tourists. Therefore, there is a vacuum of research in this field. The researcher has done a pilot survey with four officers in Tourist Police Division and two officers in Research and International Relation Division of SLTDA and two tour guides to identify the major tourists' harassments places. According to their point of view, the researcher analyzed major tourist's harassment places. They are beach sites, street, market, hotels, natural attractions, cultural sites, transportation, café. Some of their views can be pointed out as follows

\section{"Tourists harassments are one of the major issues which affect for the tourism industry not only in Sri Lanka but also in all over the world. I think beach sites and the cultural sites are highest recorded places where the tourists' harassments occur" (Personal Communication, 12.09.2018-Respondent 1).}

"I think beach sites are the most harassments occurring place in Sri Lanka. You can identify Mt. Lavinia, Mirissa, Hikkaduwa, etc. as the major hotspots for the tourists' harassments" (Personal Communication, 12.09.2018-Respondent 2).

"Most times I saw my own eyes most of the tourists faced different difficulties while enjoying their vacation. Especially women faced more difficulties than men because of the local people. According to my 25 years' experience I think beach destinations are the places where most of the tourists' harassments cases recorded specially because of the beach boys" (Personal Communication, 25.09.2018-Respondent 5)

According to the respondent ideas, it is clear beach sites are major tourist harassment places in Sri Lanka. Further, Tourists Police Related Tourist Complaints-Police Tourist Division report (RTC-PTD) mentioned that many numbers of direct common complaints received tourist police division in Colombo from the beach areas in Sri Lanka. Actually, this figure is not only received from beach sites but also common complaints received to tourists' police division in Sri Lanka by tourists. According to the Tourist Police RTC-PTD report the researcher could identify "Hikkaduwa" as a major hotspot for tourist harassment. After the pilot survey and the RTC-PTD report, the researcher decided to do the research based on tourists' harassments at beach sites with special reference to Hikkaduwa beach in Sri Lanka. It provides an idea on the types of tourist harassments and factors leading to this problem and make the recommendation to overcome to these barriers. Since tourist satisfaction is heavily reliant on the host community, and a negative experience may result in negative attitudes towards not only the hosts but also the destination.

\section{Objectives of the research}

To identify the types of harassment occurred at beach sites in Sri Lanka and the impact of them to the destination image.

To evaluate the repeat visit intention of tourists who faced harassments during their stay in Sri Lanka.

\section{Research questions}

- What are the types of harassment occurred at beach sites in Sri Lanka and the impact of them to the destination image?

- How do the tourist harassments affect to the repeat visit intention of tourists? 


\section{Significance of the study}

This study is benefiting to the tourists who visit the beach sites in Sri Lanka and also Sri Lankan Economy as a tourist destination. Based on the results of this study relevant authorities can create some successful systems and procedures to minimize the types of harassment faced by tourists in order to increase the total travel experience satisfaction. These findings help Tourist Police Division in Sri Lanka and Sri Lanka Tourism Development Authority (SLTDA) to get an idea about major harassments occurred at the beach sites and make some procedures to minimize the harassments. Further, it is important to enhance the destination image in Sri Lanka all over the world. On the other hand, the findings of the study may be useful to Destination Management Companies (DMC) to increase the repeat visitation with a high safety recommendation to the tourists.

\section{Literature Review}

Tourism comprises the activities of persons traveling to and staying in places outside their usual environment for not more than one consecutive year for leisure, business and other purposes. Therefore, tourists travel in many countries to meet their expectations. In any given tourism destination area, there are likely to be some negative impacts imposed on tourists while on vacation, whether it is unpleasant weather conditions, lack of food availability, or poor scenery. Criminal activity against tourists while traveling, such as theft, threats, violence, and harassment, has been the most commonly cited negative impacts by tourists (Skipper, 2009). Ensuring safety of tourists in the tourists' destinations is an important factor to retaining the higher number of tourist arrivals to the country since it is significance to the Economy. The standard definition for harassment is unwanted conduct on the grounds of race, gender, sexual orientation etc. which has the purpose or effect of either violating the claimant's dignity or creating an intimidating, hostile, degrading, humiliating or offensive environment for them (Abuquerque and McElroy, 2001).
Further recently, tourist harassments have been increasing in many high-density resort areas in developing countries. There, beaches are considered as the frequent hotspot of harassments (Chepkwony and Kangogo, 2013). According to McElory, Tarlow and Carlisle (2007) there are two broad types of tourists' harassments: at the macro level, institutional harassment at the hands of government officials and other authorities; and at the micro level, individual harassment at the hands of vendors and other service providers. Based on this study tourist harassments at beach sites can put at the micro level. Harassment is quite universal across the international tourist economy and takes a variety of forms. For example, selected cases of official harassment at the macro level is reported from both developed and developing regions. Further, according to the past studies, the researcher identified eight types of harassments.

Major tourists' harassments types

- Persistent venders (Exorbitant charging)

- Sexual harassment (soliciting of an unwanted sexual relationship)

- Providing unsatisfactory service (selling of substandard items)

- Physical harassment (Misappropriation)

- Theft/ Robbery

- Pestering/ Threatening/ Assault

- Cheating

- Begging

In a survey carried out by Systems Caribbean Limited in 1994, identified vendor persistence as the number one problem. Four out of five victims reported being annoyed by vendors without uniforms. This was followed by drug peddling (27\%), verbal abuse (14\%), sexual harassment $(8 \%)$ and physical abuse $(2 \%)$. Nearly all instances of sexual harassment were reported by female tourists with somewhat higher levels for European and Canadian visitors.

Tourist harassment is a service failure in the context of the consumer satisfaction. It is affecting to the quality and vacation 
experience. Harassed visitors in contrast to their non-bothered counterparts reported significantly lower levels of overall holiday satisfaction, willingness to recommend the destination to others and intention to return (Kozak, Crotts and Law, 2007). Chepkwony (2013) conducted a study "The Magnitude and Effects of Tourist Harassment on Repeat Visits: a case study of Kenya's coastal city of Mombasa" to assess the magnitude and effects of tourist harassment in Mombasa, Kenya from perspectives of tourists. Results indicated that whereas harassment was high in Mombasa. It was assumed in this study that exposure of tourist to harassment is likely to influence their future intentions to make a return visit. This study therefore tested whether harassment poses a significant threat to return visit which is key to growth of tourism in Kenya. The study sought to investigate the effects of harassment on a tourist intention to make a return visit to Mombasa. The results suggest that majority of tourists irrespective of whether they were harassed or not would still return to Mombasa for holiday. In a study done in Sri Lanka by Arachchi (2011), mentioned that the activities of beach boys as one of the major harassments causes to tourists.

Harassment can damage vacation quality, reduce the propensity to repeat and even tarnish the destination's image and the economic future (McElroy, Tarlow and Carlisle, 2007, p 310). According to the Turkey survey results regarding the impact of harassment on the quality of the vacation experience, harassed visitors in contrast to their non-bothered counterparts reported significantly lower levels of overall holiday satisfaction, willingness to recommend the destination to others and intention to return (McElroy, Tarlow and Carlisle, 2007, p 309). In a study of Rathnayake and Wijesundara in 2015 (as cited in Jacqui Allen, 1999 mentioned that the risk of serious crimes happening to any individual tourist is very low, but the intense media coverage of these sorts of events can have a major impact on the number of tourists visiting the affected locations. Further in a study of Pathirana and Gnanapala in 2015 (as cited in Chockalingam and Ganesh 2010), recognized there are fifteen problems and tourists are grouped based on their problem intensity using cluster analysis. As a conclusion they mention, the problem intensity experienced by tourists differs depending on various factors influencing tour environment. Also, the problem intensity differs significantly based on respondents' state such as gender, age, nationality, education, profession, income, geographical location, family size and frequency of tour made.

Based on the past researchers' studies, the researcher identified that most of the time tourist's harassments impact on the destination image and the propensity to repeat. Moreover, the impact of tourists' harassments to the destination image and the propensity to repeat depend on the tourists' experience, quality of the destination, tourists' satisfaction towards the destination, tourists' perception towards the destination and loyalty of the destination.

\section{Methodology}

The study carried out using the mix methodology. Both qualitative method and quantitative method used to carry out the study. According to the pilot survey, the researcher identified the beach areas as major harassment places. Based on the Tourist Police RTC-PTD report the researcher identified Hikkaduwa beach site as the major hotspot for tourists' harassments in Sri Lanka. Therefore, Hikkaduwa site was selected for the study. The researcher collected primary data for this research through a questionnaire survey, site observations and interviews with community members, site guides, security officers, officers who work in tourism related organization (SLTDA). Based on the past research findings, the researcher identified that there are more types of harassments faced by the tourists at beach sites. Further, the researcher noticed that most of the time tourists' harassments spoiled the tourist's tourism experience and as a result of that tourists dissatisfy with the tour. Then it directly affects for the destination image and the propensity to repeat which means types of 
tourists' harassments diminish the impression of the destination or propensity to repeat.

\section{Conceptualization}

Based on the past research findings and literature review, the researcher identified that there are more types of harassments faced by the tourists at beach sites. Similarly, the researcher recognized that most of the time tourists' harassments spoiled the tourists' tourism experience. Then it directly affects for the destination image and the propensity to repeat. Types of tourists' harassments diminish the impression of the destination or propensity to repeat. According to these studies, the researcher developed the conceptualization to identify the types of tourist harassments and the impact of them to the destination image and the propensity to repeat.

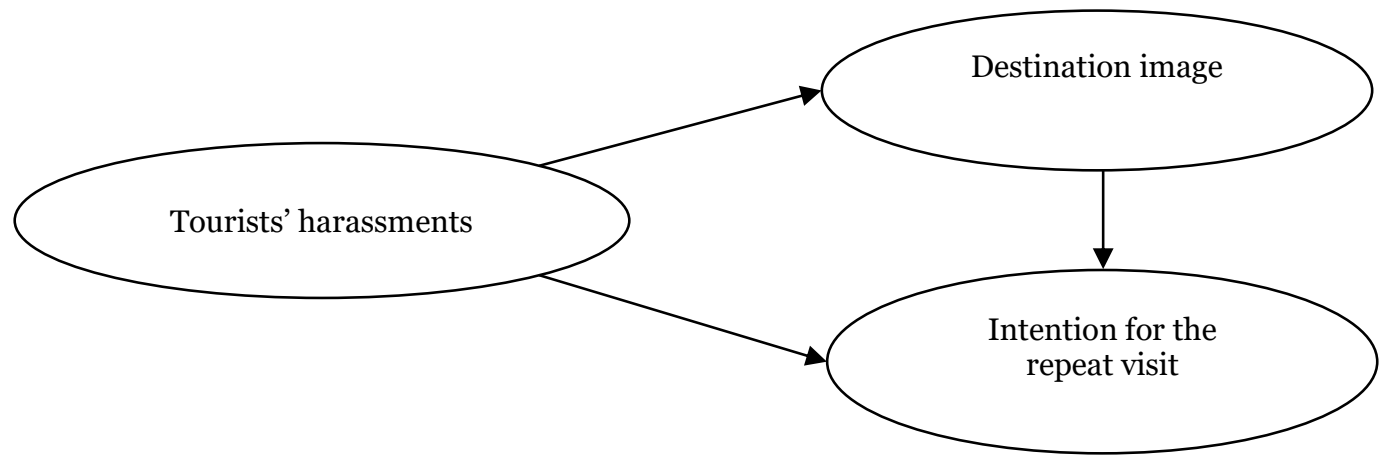

Figure 1: Conceptual Framework

\section{Hypothesis}

H1: There is a strong relationship between tourists' harassments and destination image

$\mathrm{H} 2$ : There is a strong relationship between tourists' harassments and intention for the repeat visit

H3: There is a strong relationship between destination image and intention for the repeat visit

$\mathrm{H} 4$ : There is a mediating effect of destination image to the relationship between tourists' harassments to the intention for the repeat visit

The population of the research consists with tourists who are within concern period at Hikkduwa beach site. The researcher used convenience sampling method to select the respondents for the questionnaire survey.
Since the sample framework is unknown, the researcher had to use this method. Further, snowball sampling method was used to select the respondents for the interviews of the study. Sample size consists with the tourists who visited Hikkaduwa beach site in Sri Lanka. The researcher selected 100 respondents (tourists) who visited Hikkaduwa beach site within concern period (2018 September to March 2019) to do the questionnaire survey. As a result of terrorist activity in April 2019, arrivals of tourists to Sri Lanka were dropped. Therefore, the researcher had to limit the sample size to 100 .

This framework was developed based on the past literature. Indicators for the variables were identified and those indicators were operationalized through the questionnaire. Following tables depicts the summary of them. 
Table 1: Operationalization in the questionnaire

\begin{tabular}{|c|c|c|}
\hline Variable & Indicator & Authors \\
\hline \multirow[t]{8}{*}{$\begin{array}{l}\text { Tourist } \\
\text { harassments }\end{array}$} & $\begin{array}{l}\text { Persistent } \\
\text { vendors }\end{array}$ & $\begin{array}{l}\text { McElory, Tarlow and Carlisle (2007), Chepkwony and } \\
\text { Kangogo, (2013), Skipper, (2009), Pathirana and Gnanapala } \\
\text { (2015) }\end{array}$ \\
\hline & $\begin{array}{l}\text { Sexual } \\
\text { harassment }\end{array}$ & $\begin{array}{l}\text { Chepkwony and Kangogo, (2013), Skipper, (2009), } \\
\text { Pathirana and Gnanapala (2015) }\end{array}$ \\
\hline & $\begin{array}{l}\text { Providing } \\
\text { unsatisfactory } \\
\text { service }\end{array}$ & $\begin{array}{l}\text { McElory, Tarlow and Carlisle (2007), Skipper, (2009), } \\
\text { Pathirana and Gnanapala (2015) }\end{array}$ \\
\hline & $\begin{array}{l}\text { Physical } \\
\text { harassment }\end{array}$ & Skipper, (2009), Pathirana and Gnanapala (2015) \\
\hline & Theft/robbery & Pathirana and Gnanapala, (2015) \\
\hline & Pestering/assault & McElory, Tarlow and Carlisle (2007) \\
\hline & Cheating & Pathirana and Gnanapala (2015) \\
\hline & Begging & $\begin{array}{l}\text { Chepkwony and Kangogo, (2013), } \text { Rathnayake \& } \\
\text { Wijesundara,( 2015), }\end{array}$ \\
\hline \multirow[t]{3}{*}{$\begin{array}{l}\text { Destination } \\
\text { image }\end{array}$} & $\begin{array}{l}\text { Quality of the } \\
\text { destination }\end{array}$ & \multirow[t]{3}{*}{$\begin{array}{l}\text { McElory, Tarlow and Carlisle (2007), Rathnayake \& } \\
\text { Wijesundara,( 2015), Skipper, (2009) }\end{array}$} \\
\hline & $\begin{array}{l}\text { Tourist } \\
\text { perception } \\
\text { towards the } \\
\text { destination }\end{array}$ & \\
\hline & $\begin{array}{l}\text { Tourist } \\
\text { satisfaction } \\
\text { towards the } \\
\text { destination }\end{array}$ & \\
\hline $\begin{array}{l}\text { Intention } \\
\text { for repeat } \\
\text { visit }\end{array}$ & $\begin{array}{l}\text { Loyalty to the } \\
\text { destination }\end{array}$ & $\begin{array}{l}\text { Pathirana and Gnanapala (2015), Chepkwony and Kangogo, } \\
\text { (2013), Molina de Aragon, (2007), King (2003) }\end{array}$ \\
\hline
\end{tabular}

Table 2: Variables and indicators of the research

\begin{tabular}{|l|l|c|}
\hline \multicolumn{1}{|c|}{ Variable } & \multicolumn{1}{|c|}{ Indicator } & Questions \\
\hline Tourist harassment & Harassment experience & $1-7$ \\
\hline Destination image & Quality of the destination & $15-14$ \\
\cline { 2 - 3 } & $\begin{array}{l}\text { Tourists perception towards the } \\
\text { destination }\end{array}$ & $19-24$ \\
\cline { 2 - 3 } & $\begin{array}{l}\text { Tourists satisfaction towards } \\
\text { the destination }\end{array}$ & $25-28$ \\
\hline Intention for the repeat visit & Loyalty of the destination & \\
\hline
\end{tabular}

Reliability of the questionnaire was measured using the Cronbach's alpha value method. If the corresponding alpha value of a given set of questions, less than 0.6 are considered to be poor, those in the 0.7 range acceptable and those over 0.8 good (Sekaran $\&$ Bougie, 2010). This study employed Likert scale to measure all the variables.
Keiser - Meyer - Olkin (KMO) was used to measure of sampling adequacy and Bartlett's test of Sphericity was used to decide the appropriateness of factor analysis to test the construct validity. When the significant level of Bartlett's test of Sphericity is less than 0.05 , results of the factor analysis can be accepted. For the analyzing part of this 
research study, the researcher has used descriptive statistics as examples for showing percentages of each variable.

Statistical Package for Social Sciences (SPSS) 21.0 and MS Excel were used as software to analyze the data. Efficient of regression analysis represents the degree to which extent the dependent variable is change due to the changes of a certain independent variable while other independent variables are constant. Significant level ( $\mathrm{P}$ - value) of B coefficient is used to test hypotheses. If $\mathrm{P} \leq 0.05$, alternate hypothesis is supported and can be used to make prediction. If $\mathrm{P}>0.05$ the alternate hypothesis is rejected (Cui 2011). Other than multiple and simple regression analysis, some supportive statistical techniques were used in the study.

\section{Data analysis}

According to the results of reliability statistics, Cronbach's Alpha value of each variable is greater than 0.7 . Therefore, it is possible to conclude that all the questions are reliable to measure the independent variables (tourists' harassments), the dependent variable (Intention for repeat visit) and the mediator (destination image).

Table 3: Reliability Analysis

\begin{tabular}{|l|l|c|c|}
\hline \multicolumn{1}{|c|}{ No } & \multicolumn{1}{|c|}{ Variables } & Alpha Values & Comments \\
\hline 1 & Tourists harassments & 0.969 & Acceptable \\
\hline 2 & Destination image & 0.965 & Acceptable \\
\hline 3 & intention for the repeat visit & 0.927 & Acceptable \\
\hline
\end{tabular}

According to the results of the validity statistics, Kaiser-Meyer-Olkin measure of sampling adequacy of this is 0.780 and it's over the accepted index (Above 0.5) and significance level is 0.000 . KMO value is above the 0.5 . Therefore, it confirms the validity of the model with adequate sample size.

\section{Harassment Experience}

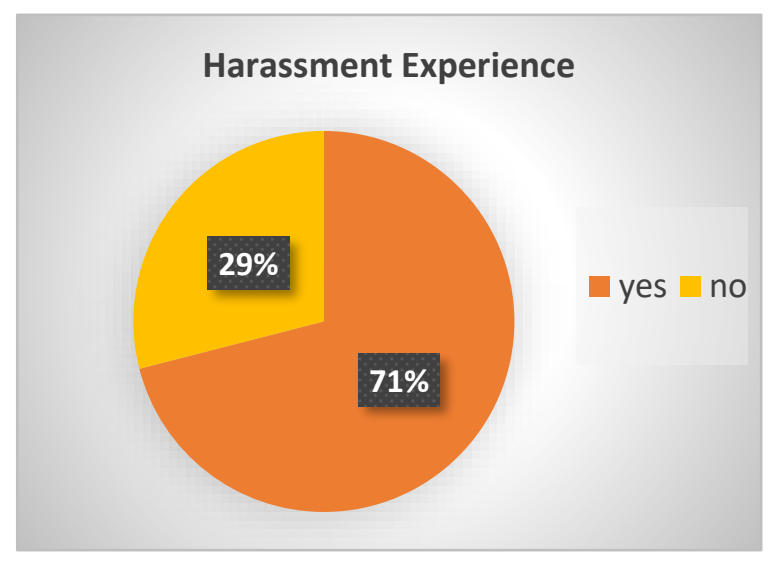

Figure 2: Harassment Experience

The figure 2 shows the experience level of harassments. Here 71 respondents (71.0percent) of the sample experience various harassments. 29 respondents (29.0 percent) of the sample do not experience any kinds of harassments.

\section{Harassment Types}

The first objective of the study is to identify the types of harassments faced by tourists during their stay in Sri Lanka. Based on the questionnaire findings, it can be simply analyzed as follows. According to below figure, 71 respondents (30.0 percent) of the sample harassed by the persistent vendors. 7 respondents (3.0 percent) of the sample experienced the sexual harassment.11 respondents (4.0 percent) of the sample harassed by providing unsatisfactory service. 2 respondents (1.0 percent) experienced physical harassment (Misappropriation). 4 respondents (2.0 percent) of the sample experienced the robbery. 3 male respondents (1.0 percent) of the sample experienced the assault. 69 respondents (29.0 percent) of the sample experienced cheating. 71 respondents (30.0) of the sample faced harassments from vendors and begging. 


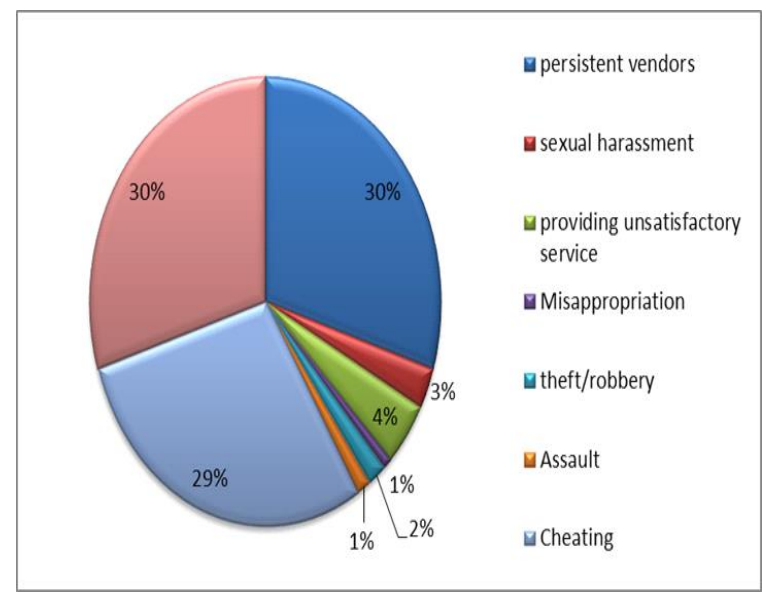

Figure 3: Harassment Types

According to the results, persistent vendors, cheating and begging can be identified as the major types of tourists' harassments which experienced by the tourists at Hikkaduwa beach site.

\section{Pearson's Correlation Analysis}

Pearson's Co-efficient of correlation shows the linear relationship between two variables and its value (r) range from $(-1$ to +1$)$. If $\mathrm{r}>$ 0.5 with high significant level $(\mathrm{P}<0.05)$, there is a strong positive relationship between two variables. If $r>-0.5$ with high significant level $(\mathrm{P}<0.05)$, there is a strong negative relationship between two variables. If ' $r$ ' close to 0 value with high significant level $(\mathrm{P}<0.05)$, there is a least negative or least positive relationship between two variables.

Table 4: Correlation Analysis

\begin{tabular}{|l|l|l|l|}
\hline \multicolumn{1}{|c|}{ Variables } & \multicolumn{1}{|c|}{$\begin{array}{c}\text { Pearson } \\
\text { value }\end{array}$} & \multicolumn{1}{|c|}{$\begin{array}{c}\text { Significant } \\
\text { value }\end{array}$} & \multicolumn{1}{c|}{ Comments } \\
\hline $\begin{array}{l}\text { Tourists harassments and the destination } \\
\text { image }\end{array}$ & -.928 & 0.000 & $\begin{array}{l}\text { Strong negative } \\
\text { relationship }\end{array}$ \\
\hline $\begin{array}{l}\text { Tourists harassments and the intention } \\
\text { for repeat visit }\end{array}$ & -.940 & 0.000 & $\begin{array}{l}\text { Strong negative } \\
\text { relationship }\end{array}$ \\
\hline $\begin{array}{l}\text { Destination image and the intention for } \\
\text { repeat visit }\end{array}$ & .913 & 0.000 & $\begin{array}{l}\text { Strong positive } \\
\text { relationship }\end{array}$ \\
\hline
\end{tabular}

Note: **. Correlation is significant at the 0.01 level $(2-$ tailed $)$

According to the table 4, it can be clearly identified that the Pearson correlation between independent variable of tourists' harassments and the dependent variable of revisit intention was $-.940 \quad(94.0 \%)$. Therefore, it that there is a strong negative relationship between two variables. In addition to that significant was 0.000 . Consequently, it implied that correlation is significant at the 0.05 level. Therefore, Tourist harassments and propensity to repeat was significant.

According to the table 4, it can be clearly identified that the Pearson correlation between independent variable of tourists' harassments and mediating variable destination image was -.928 (92.8\%). Hence, it was proved that there is a strong negative relationship between two variables. In addition to that significant was 0.000 . Consequently, it implied that correlation is significant at the 0.05 level. Therefore, Tourist harassments and the destination image was significant and in relationship. Further, it can be clearly identified that the Pearson correlation between mediate variable destination image and dependent variable propensity to repeat was $.913(91.3 \%)$. Therefore, it proved that there is a strong positive relationship between two variables. In addition to that significant was 0.000. Consequently, it implied that correlation is significant at the 0.05 level. Hence, Destination image and propensity to repeat was significant. 
Table 5: ANOVA Test

\begin{tabular}{|l|c|c|c|c|c|}
\hline \multicolumn{1}{|c|}{ Model } & $\begin{array}{c}\text { Sum of } \\
\text { Squares }\end{array}$ & df & Mean Square & F & Sig \\
\hline $\begin{array}{l}\text { Regression } \\
\text { Residual } \\
\text { Total }\end{array}$ & 60.734 & 1 & 60.734 & 749.428 & $.000 \mathrm{~b}$ \\
\cline { 2 - 6 } & 7.942 & 98 & .081 & & \\
\cline { 2 - 6 } & 68.676 & 99 & & & \\
\hline
\end{tabular}

a. Dependent Variable: PR6 b. Predictors: (Constant), HE8 Source: (Field survey 2017)

Analysis of Variance (ANOVA) test shows that the regression model is significant since the significant $\mathrm{P}$ value is 0.000 which is less than 0.05 .

\section{Regression Analysis}

Simple regression analysis is concerned with the study the relationship between independent variables and dependent variables. It tries to measure the relationship level quantitatively. According to this research, dependent variables are destination image and propensity to repeat and the independent variable is tourists' harassments. Multiple Regression analysis is concerned with the study of dependence of variables (dependent variables) on independent variable. B coefficient of the table represents the degree to which extent dependent variable can be affected by a certain independent variable. If the beta value is positive, it indicates that there is a positive relationship between the predictors and the outcomes while negative coefficient indicates a negative relationship between the predictors and the outcomes.

Table 6: Coefficient table

\begin{tabular}{|l|l|c|c|}
\hline \multicolumn{1}{|c|}{ Model } & \multicolumn{1}{|c|}{ Regression Type } & $\begin{array}{c}\text { Unstandardized } \\
\text { coefficient }\end{array}$ & Sig. \\
\hline Constant & Simple regression analysis 1 & 4.827 & .000 \\
HE8 & Dependent variable PR6 & -.644 & .000 \\
\hline Constant & Simple regression analysis & 5.061 & .000 \\
HE8 & Dependent variable DI16 & -.682 & .000 \\
\hline Constant & Simple regression analysis 3 & .300 & .007 \\
DI16 & Dependent variable PR6 & .851 & .000 \\
\hline Constant & Multiple regression analysis 1 & 3.459 & 0.000 \\
DI16 & & 0.270 & 0.001 \\
HE8 & & -.460 & 0.000 \\
\hline
\end{tabular}

In simple regression analysis $1, \mathrm{~B}$ coefficient for Tourists harassments is -.644 indicates that increasing 1 unit of tourists' harassments causes to decrease propensity to repeat in 0.644 units. This conclusion can be done with $100 \%$ confident interval. Because, significant value is 0.000 which denotes the probability of rejecting this conclusion is $0 \%$. In simple regression analysis 2 , B coefficient for Tourists harassments is -.682 indicates that increasing 1 unit of tourists' harassments causes to decrease the destination image in 0.682 units. This conclusion can be done with $100 \%$ confident interval. Because, significant value is 0.000 which denotes the probability of rejecting this conclusion is $0 \%$. In simple regression analysis 3 , B coefficient for Tourists harassments is .851 indicates that increasing 1 unit of destination image causes to increase the propensity to repeat in 0.851 units. This conclusion can be done with $100 \%$ confident interval. Because, significant value is 0.000 which denotes the probability of rejecting this conclusion is $0 \%$. $\mathrm{B}$ value is 0.270 . It is greater than 0.05 $(0.270>0.05)$. Therefore, it is clear that 
destination image is also acting as a "Mediator". Finally, the equation can be written as follows by using independent, mediate and dependent variables.

\section{Simple Regression Equation}

$\mathrm{Y}=\beta 0+\beta 1 \mathrm{X} 1$

Simple Regression Equation

$\mathrm{Y}=\beta 0+\beta 1 \mathrm{X} 1+\beta 2 \mathrm{X} 2$

Equation $1 \quad \mathrm{Y}=4.827-0.644 \mathrm{X} 1$

Equation $2 \quad \mathrm{Y}=5.061-0.644 \mathrm{X} 1$

Equation $3 \quad \mathrm{Y}=0.300+0.851 \mathrm{X} 1$

Equation $4 \quad Y=3.459+0.270 X 1-0.460 X 2$

\section{Hypothesis Testing}

Hypotheses can be tested by using the P value (sig level) of each $B$ coefficient of independent variables. Confident interval of accepting hypotheses in social sciences is 95\%. To achieve this confident interval, P value should be equal to or less than 0.05 . If it is not equal to or less than 0.05 , null hypotheses cannot be rejected. In another way alternate hypothesis is not supported.

H1: There is a strong relationship between tourists' harassments and destination image

$\mathrm{H} 2$ : There is a strong relationship between tourists' harassments and propensity to repeat

H3: There is a strong relationship between destination image and propensity to repeat
$\mathrm{H} 4$ : There is a mediating effect of destination image to the relationship between tourists' harassments to the propensity to repeat.

According to the coefficient table under the simple regression $1, \mathrm{P}$ value of the parameter of the variable tourists' harassment is 0.000 . Since it is less than 0.05 there are enough evidence to reject $\mathrm{H}_{0}$. Hence it can conclude as types of tourists' harassments impact on the propensity to repeat. According to the coefficient table under the simple regression 2 , $\mathrm{P}$ value of the parameter of the variable tourists' harassment is 0.000 . Since it is less than 0.05 there are enough evidence to reject $\mathrm{H}_{0}$. Hence it can conclude as types of tourists' harassments impact on the destination image. According to the coefficient table under the simple regression $3, \mathrm{P}$ value of the parameter of the variable tourists' harassment is 0.000 . Since it is less than 0.05 there are enough evidence to reject $\mathrm{H}_{0}$. Thus, destination image impacts on the propensity to repeat.

According to the coefficient table under the multiple regression, $\mathrm{P}$ value of the parameter of the variable destination image is 0 . 000 .Since it is less than 0.05 there are enough evidence to reject $\mathrm{H}_{0}$. Therefore, the relationship between types of tourists' harassments and the propensity to repeat is mediated by the destination image.

Table 7: Hypothesis Testing Table

\begin{tabular}{|l|l|c|c|}
\hline NO & \multicolumn{1}{|c|}{ Hypothesis } & Results & Tools \\
\hline $\mathrm{H}_{1}$ & $\begin{array}{l}\text { Types of tourists' harassments impact on the } \\
\text { propensity to repeat }\end{array}$ & Accepted & Regression \\
\hline $\mathrm{H}_{2}$ & $\begin{array}{l}\text { Types of tourists' harassments impact on the } \\
\text { destination image }\end{array}$ & Accepted & Regression \\
\hline $\mathrm{H}_{3}$ & $\begin{array}{l}\text { Destination image impact on the propensity to } \\
\text { repeat }\end{array}$ & Accepted & Regression \\
\hline $\mathrm{H}_{4}$ & $\begin{array}{l}\text { The impact of types of tourists' harassments to } \\
\text { the propensity to repeat is mediate affected by } \\
\text { the destination image }\end{array}$ & Accepted & Regression \\
\hline
\end{tabular}

In addition to the questionnaire survey, the researcher conducted in-depth interviews with 2 officers of tourist police division of Galle, 2 site guides, 2 national guides, 2 tourists who stayed in Hikkaduwa, 2 hoteliers and 4 community members. Interviews were conducted with the target people about 10 to 15 minutes. All 
respondents who faced the interviews accepted tourists faced many problems and difficulties while staying at Hikkaduwa.

One community member replied:

"According to my 20 years' experience, I saw most of the tourists faced many problems while visiting Hikkaduwa" (Personal Communication, 20.11.2018Respondent 2)

One of the hoteliers is also agreed to the researcher' and also said that, "Hikkaduwa is an unplanned development area. So, the tourists who stay at Hikkaduwa faced different types of difficulties" (Personal
Communication, 04.03.2019-Respondent 4)

Galle Tourist Police Division officers also replied to this question respectively. "The answer should be yes why because I think most of the tourists who come to stay at Hikkaduwa will face more difficulties" (Personal Communication, 30.01.2019Respondent 1)

Based on the interview analysis, the researcher was able to identify the harassment types faced by the tourists. In below table, the researcher mentioned the respondents' answers respectively.

Table 8: Harassment types

\begin{tabular}{|l|c|c|c|c|c|c|c|c|}
\hline $\begin{array}{l}\text { Responde } \\
\text { nt }\end{array}$ & $\begin{array}{c}\text { Persiste } \\
\text { nt } \\
\text { vendors }\end{array}$ & $\begin{array}{c}\text { Sexual } \\
\text { harassm } \\
\text { ent }\end{array}$ & $\begin{array}{c}\text { Unsatisfact } \\
\text { ory service }\end{array}$ & $\begin{array}{c}\text { Misappropria } \\
\text { tion }\end{array}$ & $\begin{array}{c}\text { robbe } \\
\text { ry }\end{array}$ & $\begin{array}{c}\text { Assau } \\
\text { It }\end{array}$ & $\begin{array}{c}\text { cheati } \\
\text { ng }\end{array}$ & $\begin{array}{c}\text { Beg } \\
\text { gin } \\
\text { g }\end{array}$ \\
\hline $\begin{array}{l}\text { Communi } \\
\text { ty } \\
\text { member 1 }\end{array}$ & $\checkmark$ & $\checkmark$ & & $\checkmark$ & & $\checkmark$ & $\checkmark$ \\
\hline $\begin{array}{l}\text { Communi } \\
\text { ty } \\
\text { member 2 }\end{array}$ & $\checkmark$ & & $\checkmark$ & $\checkmark$ & $\checkmark$ & & $\checkmark$ & $\checkmark$ \\
\hline $\begin{array}{l}\text { Tourist } \\
\text { police } \\
\text { officers }\end{array}$ & $\checkmark$ & $\checkmark$ & $\checkmark$ & $\checkmark$ & $\checkmark$ & $\checkmark$ & $\checkmark$ & $\checkmark$ \\
\hline $\begin{array}{l}\text { Site } \\
\text { guide1 }\end{array}$ & $\checkmark$ & & $\checkmark$ & $\checkmark$ & $\checkmark$ & & $\checkmark$ & $\checkmark$ \\
\hline $\begin{array}{l}\text { Site guide } \\
\text { 2 }\end{array}$ & $\checkmark$ & & $\checkmark$ & $\checkmark$ & $\checkmark$ & $\checkmark$ & $\checkmark$ & $\checkmark$ \\
\hline Hotelier 1 & $\checkmark$ & & $\checkmark$ & & $\checkmark$ & & $\checkmark$ & $\checkmark$ \\
\hline Hotelier 2 & $\checkmark$ & & $\checkmark$ & & $\checkmark$ & & $\checkmark$ & $\checkmark$ \\
\hline Tourist1 & $\checkmark$ & & $\checkmark$ & & $\checkmark$ & $\checkmark$ & $\checkmark$ & $\checkmark$ \\
\hline Tourist 2 & $\checkmark$ & & $\checkmark$ & $\checkmark$ & $\checkmark$ & $\checkmark$ & $\checkmark$ & $\checkmark$ \\
\hline $\begin{array}{l}\text { National } \\
\text { Guide 1 }\end{array}$ & $\checkmark$ & & $\checkmark$ & & $\checkmark$ & $\checkmark$ & $\checkmark$ & $\checkmark$ \\
\hline $\begin{array}{l}\text { National } \\
\text { guide 2 }\end{array}$ & $\checkmark$ & & $\checkmark$ & $\checkmark$ & $\checkmark$ & $\checkmark$ & $\checkmark$ & $\checkmark$ \\
\hline
\end{tabular}

There are different ideas from the respondents about harassments. Majority of the respondents said that female tourists who came as FITs and young tourists faced some problematic situations in terms of harassments. Based on the comments received, the researcher identified that most of the tourists faced different types of harassments at the beach site. As a result of that, they had a bad image towards the destination. Moreover, they don't like to recommend the site for others. In this case, government involvement to apply the law, rules and regulations is very much essential to control the harassments. Further, tourist police should pay more attention to address these issues. 


\section{Recommendations and Conclusion}

\section{Recommendations}

\section{Propose a "By pass road"}

Hikkaduwa is an unplanned development area. There is a hotel complex which is established near to the road. So not like Bentota area there is no any freedom for the tourists to walk on the road independently. Especially at night most of the female tourists doesn't have any freedom to walk on the road independently due to the forceful behaviour of some Tuk Tuk drivers. They ask the tourists to take their services by force. Not only that also in Hikkaduwa there many robbery cases at night. Most of the respondents' idea is that to develop Hikkaduwa like Bentota area, responsible parties should propose a bypass road for tourists.

\section{Increase the involvement of respondent parties}

To reduce the harassments at Hikkaduwa, SLTDA and Tourist Police involvement should increase. Most of the respondentse idea was that especially tourists ${ }^{e e}$ police involvement is very low. They should monitor the beach and the roads to avoid the harassments from beach boys. To reduce the problem tourists' police should implement the law properly. Most of the person idea was that tourist police are only attending to traffic offenses. So, they should be on the spot. All the tourism stakeholders should involve to solve these problems. It is better to use 'participatory approach' of all the tourism stakeholders to reduce this issue.

\section{Establish rules and regulations}

Officials should establish some rules and regulations against the unnecessary influencers. Most of the tourists face different types of difficulties and the problems due to the local people. Especially FITs (Free Individual Travelers) face most of the problems due to the beach boys. Authorities should conduct regular inspection and licensing to remove illegal operators on the beach. Moreover, government should consider enacting laws that criminalizes harassment of tourists.

\section{Issuing identification cards for tourism stakeholders}

Responsible parties should involve issuing IDs for the Tuk Tuk drivers, site guides, fishermen. Some tourists most of the time highly depend on the support of beach boys rather than professional tour guides. Therefore, the tourists face more problems to identify real tour guides and the beach boys. Thus, the responsible parties should issue a license for the sites guides who guide at the Hikkaduwa beach area. By issuing IDs for them, the tourists can easily identify those persons separately from the influencers.

\section{Awareness programmes for the site guides.}

The officials should aware site guides by highlighting the importance of the tourists to the Sri Lankan economy. They have to emphasize the importance of tourists to the economy as well as the image of the destination

\section{Conclusion}

In this research study, the researcher tried to identify the types of tourists' harassments faced by the tourists at beach sites, the impact of tourists' harassments to the destination image and the propensity to repeat and make the recommendations to overcome this problem. To find these objectives the researcher selected Hikkaduwa beach site as the particular case study.

According to the interviewers' and the tourists responds, most of the respondents were experienced various tourists' harassments and few respondents reported that they did not experience any kind of harassments. The researcher identified persistent vendors, cheating, begging as the major tourists' harassments and the sexual harassment, providing unsatisfactory service, misappropriation, theft and assault as minor tourists' harassments. Further, the researcher identified these types of tourists' harassments impact to the destination image 
and the propensity to repeat. When the researcher is considering about the impact of tourists' harassments to the propensity to repeat and the destination image, the researcher identified there is a strong negative relationship between tourists' harassments and the propensity to repeat and the destination image. The findings of this research study suggested that the negative perception of tourist about harassments in Hikkaduwa is high. It is a big issue since it has significant link with repeat visits. The tourists' attitudes towards the quality of the destination were very low. It is also one of the problems which has significant link with the destination image and the propensity to repeat. In addition to that, most of the respondents experienced harassments while staying at Hikkaduwa. As a result, it has spoiled their vacation. Therefore, their satisfaction level was not up to their expected level. It directly affects for the destination image and the propensity to repeat. Therefore, relevant authorities such as Sri Lanka Tourism and Development Authority, Tourist Police, Ministry of Tourism must concern on this matter and take immediate actions to minimize these issues.

\section{References}

Abuquerque, K.L., McElroy, L.J. (2001). Tourist harassment: Barbados survey results. Annals of Research Study, 477492.

Arachchi, R.S.S.W. (2011). The impacts imposed by beach boys as tourism service providers on tourism industry- A case study of Induruwa (Sri Lanka). Conference proceedings- $8^{\text {th }}$ International conference on Business Management, Sri Jayewardenepura University- 2011

Bornstedt, G.W. (1977). Reliability and validity in attitude measurement. 80-99.

Bryman, A. (2006). "Integrating quantitative and qualitative research: how is it done?" Qualitative Research, Vol. 6 No. 1, pp. 97113.

Chepkwony, R. (2013). The magnitude and effects of tourist harassment on repeat visits: a case study of Kenya's Coastal City of Mombasa. International Journal of Current Research, 2978-2981.

Chepkwony, R., Kangogo, M. (2013). Nature and factors influencing tourist harassment at coastal beach of Mombasa, Kenya. International Research Journal of Social Sciences, 2(11),17-22.

Clarke, A.C. (2017). Travel with secret Lanka. Retrieved May 15, 2017, from secret lanka.com: https://www.secretlanka.com

Cui, W. (2011). Creating consumer-based brand equity in the Chinese ports' shoes market: Measurement, challenges and opportunities. Interdisciplinary Journal of Contemporary Research in Business (3), 1-201.Explorable. (n.d.). Case Study of Research Design. Retrieved July 14, 2017 , fromexplorable.com:https://explorable.co $\underline{\mathrm{m}}$

Kozak, M., Crotts, J.C., Law, R. (2007). The impact of the perception of risk on international travellers. International Journal of Tourism Research (Vol:9 Issue 4)

McElroy, J.L., Tarlow, P., Carlisle, K. (2007). Tourist harassment and responses. Tourism Management, 94-105.

Pathirana, D.P., Gnanapala, W.K. (2015). Tourist harassment at cultural sites in Sri Lanka. Tourism, Leisure and Global Change, 2, 42-56.

Rathnayake, R.D., Wijesundar, W.G. (2015). Tourist perception on harassments in Sri Lanka (with special reference to Mount Lavinia). International Journal of Scientific and Research Publications, 5(4).

Skipper, T. L. (2009). "Understanding touristhostiInteractions and their influence on quality tourism experiences". Theses and Dissertations (Comprehensive). 949. https://scholars.wlu.ca/etd/949

Systems Caribbean Limited (1995), Barbados Visitor Satisfaction Surveys, 1991-1994, SCL,St Michael. 